University of Maryland Francis King Carey School of Law

DigitalCommons@UM Carey Law

1990

\title{
The Maryland Context of Dred Scott: The Decline in the Legal Status of Maryland Free Blacks 1776-1810
}

David S. Bogen

University of Maryland School of Law, dbogen@law.umaryland.edu

Follow this and additional works at: https://digitalcommons.law.umaryland.edu/fac_pubs

Part of the Law and Race Commons, and the Legal History Commons

\section{Digital Commons Citation}

Bogen, David S., "The Maryland Context of Dred Scott: The Decline in the Legal Status of Maryland Free Blacks 1776-1810" (1990). Faculty Scholarship. 766.

https://digitalcommons.law.umaryland.edu/fac_pubs/766

This Article is brought to you for free and open access by the Francis King Carey School of Law Faculty at DigitalCommons@UM Carey Law. It has been accepted for inclusion in Faculty Scholarship by an authorized administrator of DigitalCommons@UM Carey Law. For more information, please contact smccarty@law.umaryland.edu. 


\title{
The Maryland Context of Dred Scott: The Decline in the Legal Status of Maryland Free Blacks 1776-1810
}

\author{
by David SKILLEN Bogen*
}

\section{Introduction: Chief Justice Taney and the Question of Negro Citizenship in the Constitutional Era}

In Dred Scott v. Sandford, ${ }^{1}$ Chief Justice Roger Brooke Taney stated that negroes, ${ }^{2}$ whether slave or free, were not citizens of the United States. Espousing a jurisprudence of original intent, he maintained that the citizenship of negroes in 1857 depended on whether the framers of the Constitution considered free negroes to be citizens of the United States in $1787 . .^{3}$ Taney had no textual basis for his assertion that the framers intended to deny free negroes the rights of citizens. ${ }^{4}$ The Constitution did not mention race. Several clauses in the document dealt with issues arising out of the institution of slavery, but no language even hinted that race made a differ-

* Professor of Law, University of Maryland School of Law. B.A., 1962, LL.B., 1965, Harvard University; LL.M., 1967, New York University. An earlier version of this paper was presented at a conference on blacks and the constitutional era at Morgan State University. The author would like to express his appreciation for the research assistance of Tracy Downing and John Connolly. The staffs of the libraries at the University of Maryland School of Law, the Maryland Court of Appeals and the Maryland Hall of Records were extremely helpful, especially Phoebe Jacobson of the Hall of Records.

1. 60 U.S. (19 How.) 393 (1857).

2. Taney's opinion applied to a negro whose ancestors were imported into this country and sold as slaves. Although many of his remarks applied to mulattoes also, he did not fully confront the issue of the status of the individual with white as well as African ancestry. The analytic confusion surrounding mulattoes is matched by a semantic one. During the eighteenth century, Maryland laws often referred separately to negroes and mulattoes, but the distinction largely disappeared during the nineteenth century. In the source material, "free negroes" sometimes referred to negroes and mulattoes alike, sometimes to negroes as distinguished from mulattoes, and frequently remained ambiguous. Thus, in this article "negro" is sometimes used in distinction from mulatto and sometimes includes mulattoes. The term "black" as used in the article includes mulattoes. It is used whenever it is clear that both mulattoes and negroes are to be covered by a single term.

3. 60 U.S. (19 How.) at 407.

4. For example, free negroes were treated exactly as white citizens for purposes of taxation and representation while slaves counted only for three-fifths. U.S. Const. art. I, §2, cl. 3. 
ence in the constitutional rights of free individuals. ${ }^{5}$ Those who framed and ratified the Constitution did not discuss the issue. ${ }^{6}$ What influenced, and perhaps determined, Taney's understanding of original intent was not the expressions of the framers in Philadelphia in 1787, but the legal developments in his native Maryland in the nineteenth century, more than a decade later.

Roger Taney was born in 1777 , less than a year after the Declaration of Independence. ${ }^{7}$ Racial prejudice in Maryland was strong then, but, with few exceptions, the law applicable to free blacks was color-blind. In the thirty-five years following the Declaration, the ideals of freedom produced a growing free black population. Meanwhile, racial legislation deprived free blacks of many of the rights they possessed when the period opened. The disregard for the rights of free blacks displayed in the enactment of those laws as Taney grew to maturity helped persuade him that negroes "had no rights." 8 A closer examination shows that at each step that led to the destruction of the status of free blacks in Maryland, the legislature recognized the existence of rights in blacks, but each step diminished those rights until the status of free blacks under Maryland law was as bad as Taney's Dred Scott opinion reflected.

\section{Citizen or Slave-The Legal Status of Blacks in Maryland When Independence Was Declared (1776)}

When the American colonies declared their independence from England in 1776, the people of Maryland were either slaves or citizens. More

5. There were only three clauses specifically adopted to deal with issues raised by slavery, U.S. Const. art. I, $\$ 2$, cl. 3 (counting "three fifths of all other Persons" in apportioning representatives and taxes); art. I, $\S 9, \mathrm{cl} .1$ (preventing Congress from prohibiting importation of "such Persons as any of the States now existing shall think proper to admit" until 1808); and art. IV, $\$ 2$, cl. 3 (requiring delivery of persons held in service in one state back to that state); but other clauses of general import were influenced by the "peculiar institution." For example, the obligation of the United States to protect each state against domestic violence, id. art. IV, $\S 4$, had particular pertinence for delegates who feared slave revolts. Nevertheless, the word "slave" does not appear anywhere in the original Constitution, and there is no distinction between negroes and whites in that document.

6. Taney used this to argue that free negroes "were not even in the minds of the framers of the Constitution when they were conferring special rights and privileges upon the citizens of a State in every other part of the Union." Dred Scott, 60 U.S. (19 How.) at 411-12.

7. C. Swisher, Roger B. Taney 9 (1935).

8. Taney said that the descendants of Africans who were imported into this country and sold as slaves were considered at the time of the Constitution as beings who "had no rights or privileges but such as those who held the power and the government might choose to give them." Dred Scott, 60 U.S. (19 How.) at 405. 
than ninety-two per cent of all blacks in the state were slaves. ${ }^{9}$ Slaves had no legal rights. ${ }^{10}$ For purposes of the civil law, they were treated as property. ${ }^{11}$ Although slavery was linked to race, it was slavery and not race that determined the existence of civil rights.

The few blacks in Maryland who were free were citizens of the state. There were, of course, variations of rights among citizens, but age, gender and property ownership were as important as race in the exercise of these rights. Black men who owned fifty acres or had thirty dollars in assets could vote while women and poor white men could not.

One voter was Benjamin Banneker, the noted black almanac author. He was born free because his maternal grandmother was white. In 1759 Banneker inherited over 100 acres of land from his father. ${ }^{12} \mathrm{His}$ legal rights were virtually indistinguishable from those of a white man. They were described by counsel in Rusk $v$. Sowerwine, a case decided by the Court of Appeals in 1810, four years after Banneker's death: "Benjamin Bannaker [sic], a black man of Baltimore county, . . . exercised in his life the rights of a free man in holding real property, in voting at elections, and being allowed and permitted to give evidence in courts of justice in cases in which free white citizens were concerned . . .."13

Equality in legal rights should not be confused with equal treatment within the society. For example, although laws regulating runaway servants and slaves made little reference to the ethnic origin of the persons escaping from labor, skin color was the touchstone for enforcement. A white who entered a new community was presumed a free person in search of opportunity, while an unfamiliar black would be suspected of being an escaped slave. Statistically, the suspicions were accurate-almost all blacks were slaves while most whites were free and not indentured servants. That

9. In $1755,96 \%$ of all blacks in Maryland were slaves (about 1800 of 45,000 blacks were free). 2 United States Bureau of the Census, Historical Statistics of the United States: Colonial Times to 19701169 (1975). By 1790, the percentage had fallen below 93\% (8043 of 111,079 blacks were free). J. Wright, The Free Negro in Maryland: 1634-1860 92 (1921; reprint 1971). Although these statistics are problematic and the precision of the figures misleading, it is still a fair assumption that the percentage of blacks held as slaves in 1776 was between $92 \%$ and $96 \%$.

10. Slaves had a right to petition for freedom, because a court could not determine whether the petitioner was a slave without rights or a free person with rights unless it heard the petition. Slaves also received protection in the public criminal process, because the imposition of punishment by the state either impaired the value of the slave to the master or required the state to compensate the master. This was often sufficient incentive to assure relatively fair determinations of guilt or innocence in public trials. Masters' decisions to punish their slaves, however, followed no such procedural niceties.

11. Thus, in Maryland the law of slavery was largely the law of property. Other aspects of the law of slavery involved the regulation of the white community, for the regulation of slave behavior was left to the master.

12. He held the land until the 1790 s when he sold it to provide for his retirement. See S. Bedini, The Life of Benjamin Banneker 26-27, 241-44 (1972).

13. Rusk v. Sowerwine, 3 H. \& J. 97, 97-98 (Md. 1810). 
presumption, however, meant that free blacks needed to carry some document to assure their freedom, and they risked harassment if they ventured beyond their home area. In general, the formal equality of the law in the abstract never translated into equal treatment under the law.

Not only did government treat free blacks unequally under "equal" laws, private individuals discriminated against them freely as well. White racial prejudice was a substantial burden for blacks to overcome in the competition for jobs and money. Nevertheless, racial prejudice did not lead immediately to discrimination in the laws. Differences in individuals do not threaten the principle of equal treatment under law. In theory, differences attributed to race might be thought irrelevant to legal rights. Indeed, it appears unjust to add by law to the disadvantages believed to exist by nature.

Laws against interracial sexual relationships did derive from the belief in natural racial distinctions, but they preserved a form of equality. Taney argued that the antimiscegenation laws of both Maryland and Massachusetts in force at the time of the Revolution proved that blacks were not citizens. He called them a "stigma of the deepest degradation fixed on the whole race." 14 Taney correctly saw the antimiscegenation laws as proof that the white community regarded blacks as inferior and that it believed interracial sexual relations polluted the superior white race. That belief, however, for a time seemed compatible with a recognition of equality in legal rights and the privileges of citizenship. All free men were entitled to the same civil rights, but the races were to be kept from mixing.

A Maryland statute prohibited a white woman from marrying a free black like Banneker or having a child by him, just as it forbade the free black from marrying or having a child with her. The statute is evidence of a social taboo. It imposed substantial risks on interracial sexual relationships, even if it was not always enforced. ${ }^{15}$ Ministers in Maryland were subject to

14. Dred Scott, 60 U.S. (19 How.) at 409.

15. Enforcement required someone with an interest in acting. The servitude imposed by law involved offering the individual for service to the highest bidder. An individual who desired labor would be more likely to want slaves or white laborers than an infant or the man or woman convicted for having the interracial child. Allowing the couple to remain free could be just as remunerative for the community - they could care for the child in infancy and they might pay taxes. Local communities could, of course, prosecute if they were so inclined. Where the interracial relations were adulterous, the spouse had an interest in prosecuting to provide grounds for divorce. For example, in the 1794 session of the House of Delegates, two white men petitioned for a divorce on the grounds that their wives committed adultery with a mulatto or negro. Schoolfield Parker got his divorce when he showed that his wife had been convicted in county court of adultery and of having a mulatto child and that she was sold as a servant. Votes and Proceedings of the Maryland House of Delegates [hereinafter VPMHD] Nov. Sess. 1794, 7-8, 10, 112. Moses LeCompte's wife had not been convicted of adultery in any court of the state. LeCompte was a Methodist who supported the manumission of slaves. Carroll, Religious Influences on the Manumission of Slaves in Caroline, Dorchester, and Talbot Counties, 56 Md. Hist. Mag. 176, 191 n.70 (1961) [hereinafter Carroll]. He apparently was loathe to bring an action that would condemn his wife and her lover to servitude. Thus, although the House Committee found that his accusation was true, the legislature refused to grant him a divorce. VPMHD (1794), supra, at 63. 
punishment for marrying any white person to a negro or mulatto. ${ }^{16}$ If such a marriage did occur, both husband and wife were liable to a sentence of servitude. ${ }^{17}$ An interracial couple who had a child were punishable by servitude, whether they were married or not, and the statutes even provided that their child would be a servant for thirty-one years. ${ }^{18}$ Thus, the antimiscegenation laws condemned free blacks, their white partners, and their mulatto children to servitude.

The one clear racially discriminatory law dealt with evidence in cases involving whites. The statute that outlawed interracial marriage also declared that

16. $1715 \mathrm{Md}$. Laws ch. $44, \S 24$. The printed series of Maryland laws began in 1727 along with the first printing of the Votes and Proceedings of the Maryland Senate thereinafter VPMS] and VPMHD. L. Wroth, History of Printing in Colonial Maryland 1686-1776 63 (1922). A compilation of the laws in force through 1718 was published by Andrew Bradford. The Laws of the Province of Maryland, Collected into One Volumn [sic] (1718). It contained no section numbers. When the early laws were reprinted in later compilations, they were given section numbers to conform with the style used in T. Bacon, Laws of Maryland at Large (1765) which followed the sectioning format frequently used in earlier printed annual session laws. The section following a preamble was numbered 2 . The style changed in 1811 to begin with section 1 after the preamble. Standard compilations of the nineteenth century retained the original format of section numbering in printing the laws, but often confused matters by using the new numbering system in cross references. The section numbering throughout this paper reflects the section number used in the annual printed session laws. With respect to early laws which had no section numbers, the section numbers in this paper are based on the compilation of statutes in force in 1809. The Laws of Maryland (V. Maxcy ed. 1811) (3 vols.).

17. The statute stated that a negro or mulatto who married a white person "shall become a servant for life" to be disposed of by the county court with the proceeds to be devoted to the support of public school. The punishment of lifetime slavery did not apply if the mulatto was born of a white woman. In that event, the mulatto marrying a white person became a servant for only seven years. The white spouse of the negro or mulatto was also liable to become a servant for seven years. $1717 \mathrm{Md}$. Laws ch. 13, §5.

The enslavement of the free black as punishment demonstrates the racial nature of slavery and the willingness of the General Assembly to make distinctions on racial grounds, and emphasizes the nature of the antimiscegenation law as a prohibition enacted for the benefit of whites. It does not contradict the statement in the text on equal civil rights, but that statement must be understood as referring only to what behavior is or is not permitted or protected, and not the degree of punishment for prohibited behavior.

18. If a white woman had a child by a negro, both mother and father (if the father was free) were to be punished by seven years of servitude. The child in turn was to be a servant until the age of $31.1715 \mathrm{Md}$. Laws ch. $44, \S \S 25-26$. The white father of a child by a negro woman was similarly to be punished with seven years servitude, id. \$27. Free negro women "having bastard children by white men" were subject to the same penalties and their children subject to the same consequences as white women who had children by negroes. 1728 Md. Laws ch. 4, \$3. Finally, free mulatto women, "having bastard children by negroes and other slaves" were also subject to seven years service and the children to 31 years of service. Id. preamble, $\$ 2$. Slaves lacked the legal capacity to marry, so any child fathered by a slave was illegitimate and subject to 31 years of servitude. Free negroes could marry mulattoes, and their children would be free. But the free daughter of a mulatto and a negro was punishable for having a child by a slave, and her child would be subject to servitude. Higgins v. Allen, 3 H. \& McH. 504 (Md. 1796). 
no negro or mulatto slave, free negro, or mulatto born of a white woman, during his time of servitude by law, or any Indian slave, or free Indian natives, of this or the neighbouring provinces, be admitted and received as good and valid evidence in law, in any matter or thing whatsoever depending before any court of record, or before any magistrate within this province, wherein any christian white person is concerned. ${ }^{19}$

This statute was inartfully drawn. It barred the testimony of the mulatto born of a white woman during his period of servitude by law, but it is unclear whether the ban applied to mulattoes under thirty-one if the antimiscegenation law imposing servitude on the child had not been enforced against them. It omitted the case of the mulatto born to a free negro woman. Even the ban on free negro testimony was ambiguous, because the modifier- "during his time of servitude by law"-could be read to apply to the free negro as well as the mulatto born of a white woman. ${ }^{20}$ In practice, the statute was probably interpreted to exclude the evidence of all free negroes just as it excluded the testimony of free Indians. The statute reflected a determination not to allow the rights of whites to depend on blacks. It introduced race into trials, and evidenced a greater willingness to allow evidence from someone with at least one white ancestor. A Benjamin Banneker might be able to testify while his father, though free, could not.

While the statute reeks with racial prejudice in its sharp suspicion of the veracity of negroes, mulatto servants and slaves, in the eighteenth century it would have been possible to argue that this exclusionary rule did

19. 1717 Md. Laws ch. 13, §2. Mulattoes punished by servitude under the antimiscegenation law were, like slaves, at the mercy of a master not of their choosing. One reason for the law may have been the belief that their testimony would be determined by their master, or would be in rebellion against him-in either event, that it would be shaped by the master-servant relationship.

20. Under one reading, the limiting phrase in section 2 of the 1717 statute-“during his time of servitude by law"-modifies only "mulatto born of a white woman." The law then would exclude the testimony of all free negroes in any matter wherein any Christian white person is concemed. This is consistent with the judicial decisions at the beginning of the nineteenth century discussed infra.

Alternatively, "during his time of servitude by law" may apply to every group named to that point, including the free negro. Under this reading, the testimony of free negroes would be admissible if they were not under legally imposed servitude.

The Laws of the Province of Maryland, Collected into One Volumn [sic], supra note 16 at 199 , omits the comma between free negro or mulatto in $\$ 2$ of chapter 13 although the comma is included in later compilations which may have been based on the original records. Unfortunately, the volume of the State Archives which contained the record of the 1717-20 Session laws has long been lost. 33 Maryland Archives x (C. Hall ed. 1913). The application of the modified term "during his time of servitude" to the free negro is grammatically more appropriate if the punctuation of the 1718 compilation is accepted.

A 1783 statute prohibited slaves freed after that date from testifying in cases involving whites. 1783 Md. Laws Apr. Sess. ch. 23, §3; 1796 Md. Laws ch. 67, §5. This suggests that free negroes had not previously been barred from giving testimony in such cases, but it may have been a response only to the evidence of freed mulatto slaves who were not covered by the 1717 law. 
not deny free blacks any civil right. At the time, parties could not testify in their own behalf. ${ }^{21}$ Testifying on behalf of another could be considered an obligation, like military service, rather than a right. Black litigants received the same rights as whites in litigation in which both races were involved. ${ }^{22}$ This equality was theoretical; racial exclusion of evidence worked a practical inequality. The testimony of slaves and free black servants might have been of special utility to free black litigants, and the racial overtones of the rule suggest an atmosphere of prejudice that could have infected the entire courtroom. Nevertheless, the exclusion of slave, negro or mulatto servant testimony did not on its face injure the free black in the exercise of basic civil rights of contract, property and recourse to the courts.

The few remaining racial distinctions in the law applicable to free blacks in 1776 did not contradict the general principle of an abstract equality in civil rights for all free men. ${ }^{23}$ In view of the evidentiary exclusion, it would not be surprising if free negroes were excluded from voting, serving on juries and holding office, but no such lines were drawn in the statutes. ${ }^{24}$ Free blacks possessed all the basic civil rights of white persons - the right to contract, to possess property, to sue and even to vote. Thus, despite slavery and rampant racial prejudice, it was possible to characterize the legal situation in 1776 as one based on the principle of

21. "A party to the suit on record cannot be witness at the trial for himself or for a joint suitor, against the adverse party, on account of the immediate and direct interest which he has in the event, either from having a certain benefit or loss, or from being liable to costs." $J$. LaTrobe, The Justices' Practice Under the Laws of Maryland 332 (1826). See also J. Hall, The Office and Authority of a Justice of the Peace in the State of Maryland 124 (1815). For discussions of the history of this now obsolete rule, see 2 Wigmore, Evidence \$\$577-578 (Chaclbourn Rev. 1979) and IX W. Holdsworth, A History of English Law 193-97 (3d ed. 1944). See also W. Twining, Theories of Evidence: Bentham and Wigmore 21-22 (1985) (pointing out that the evidentiary rule of the incompetency of parties was an easy target for Bentham to attack in 1827).

22. On the face of the statute, the exclusion of slave or black servant evidence applied whether the evidence was to be used for or against the white Christian. $1717 \mathrm{Md}$. Laws ch. 13, $\S 2$. Further, discussions in the legislature and the wording of subsequent legislation indicate that slave and black servant testimony was also excluded in criminal proceedings against free blacks and mulattoes. VPMHD (1792), supra note 15, at 98; 1801 Md. Laws ch. 109 . It is possible that such testimony was admissible in actions between free blacks, but given the small number of free blacks in the state, such a suit would be a rare occurrence.

23. No one had a right to entertain or harbour a servant or a slave unlawfully absent from home, although free blacks who violated the law could have received a somewhat greater punishment than was applicable to whites. $1715 \mathrm{Md}$. Laws ch. $44, \S \S 4-5$. Similarly, no right was involved in exclusions from military service, since that is a duty rather than a civil right. Liability to military service fluctuated according to the perceived need for soldiers: it was limited to whites in 1777 , extended to blacks in 1780, and limited again to whites in 1792 . See J. Brackett, The Negro in Maryland 196-97 (1889 \& reprint 1969).

24. Election judges in Annapolis in 1800 made no apparent distinction in eligibility between free negroes and mulattoes among free black voters, deciding only whether the prospective voter had been born free. Bogen, Black Voting in Maryland in the Early Republic: The Annapolis Polls of 1800 and 1804, 85 Md. Hist. Mag. (forthcoming). 
equality for all free men. Slaves had no civil rights. All other persons, regardless of race, had the same civil rights.

This legal situation was unstable. The equal status of free blacks and whites as citizens clashed with the racially exclusive nature of slavery. Emancipation undermined the dichotomy of slave and citizen and enabled some individuals to move from one status to another. The growth of the free black population highlighted these inconsistencies and prompted a new response.

\section{Citizen, Slave or Newly Free Black-The Legal Status of Blacks in Maryland When the Constitution was Adopted (1787)}

Although free blacks clearly were citizens of Maryland when independence was declared in 1776, their status had altered significantly by 1787, when the Constitution was adopted. The change came in 1783 when Maryland added a third category to the previous division of society into slaves and citizens. The new category was a status in limbo-free blacks denied the rights of freemen. Ironically, it was the by-product of a law prohibiting the importation of slaves into Maryland.

In 1783 Maryland outlawed the importation of slaves from other states as well as from foreign countries. ${ }^{25}$ The statute had many novel features, yet the innovations were designed to preserve the status quo in a time of change. The importation of slaves from abroad had abated by 1775 , after Maryland ratified the resolution of the Continental Congress against the importation of goods from Great Britain, Ireland or the East or West Indies. The Revolutionary War hobbled the slave trade for a number of years thereafter. ${ }^{26}$ In 1780 the Maryland legislature enacted a tax that effectively prohibited the importation of slaves from abroad ${ }^{27}$ Thus, the 1783 statute forbidding the importation of slaves did not end an existing trade; it merely prevented a return to earlier behavior.

25. 1783 Md. Laws Apr. Sess. ch. 23. Any slave brought into the state in contravention of the statute became free. There were two major exceptions to the prohibition on bringing slaves into the states. United States citizens from other states could bring their slaves with them when they immigrated to Maryland. Travelers or sojourners in the state were allowed to bring their slave with them if they took the slave with them when they left. Finally, the statute specified that no person brought into the state who was not a slave for life in the state from which he was brought should be considered a slave in Maryland, although he would still be obliged to service for the same period of time as he was obliged to do under the laws of the state from which he came.

26. See D. Mannix \& M. Cowley, Black Cargoes: A History of the Atlantic Slave Trade 169-70 (1962).

27. $1780 \mathrm{Md}$. Laws June Sess. ch. $8, \S 10$. The law taxed the importation of negro slaves at 500 pounds currency; except that the tax was only 15 pounds for slaves who had been living in one of the United States for more than three years before being brought to Maryland, and there was no tax on persons entering the state to reside and bringing with them slaves not intended for sale. Id. 
The importation of slaves was no longer the most significant agent of change in race relationships. The growing antislavery movement had far greater potential, for it affected both the size and the nature of the free black population in the state.

In 1755 , eighty percent of all free blacks were mulattoes. A disproportionate number of the remaining free blacks were old or disabled, which indicates that they had been freed by a master seeking to avoid responsibility for their care and that their children were unlikely to be free. ${ }^{28}$ The acknowledgment of full legal rights to persons of mixed race was not terribly threatening. Most free "blacks" were half white; and the social as well as legal taboo against interracial sexual relations effectively limited the percentage of free mulattoes in the general population. Over the next three decades, the religious ideas of the Quakers, Nicholites and Methodists combined with the political ideals of the Revolution to foster manumission of greater numbers of blacks. ${ }^{29}$ Legislators could contemplate a society that included a few mulatto citizens descended from white women. After all, mulattoes not under servitude were trusted to testify in suits involving whites. But white lawmakers resisted accepting negroes as members of their community.

Manumission also threatened to change the political structure of the society. In 1783 the numbers of free blacks were still proportionately small but the antislavery movement was growing in strength. Neighboring Pennsylvania was phasing out slavery, ${ }^{30}$ and other states, including Maryland, soon would be considering abolition laws. ${ }^{31}$ Legislators could foresee that

28. Historical Statistics, supra note 9, at 1169 . Fifty-eight of the 357 free negroes in 1755 were not taxable because they were too old or otherwise disabled, lending credence to the claim that masters tended to free slaves during the period prior to the 1752 statute as a means of evading the duty to care for them when they were no longer a profitable asset. In 1752 the legislature prohibited the manumission of slaves over the age of 50 or otherwise disabled from work. 1752 Md. Laws June Sess. ch. 1.

29. See Carroll, supra note 15. See also Carroll, Joseph Nichols and the Nicholites of Caroline County, Maryland, 45 Md. Hist. Mag. 47 (1951); Carroll, More about the Nicholites, 46 Md. Hist. Mag. 278 (1951).

30. An Act for the Gradual Abolition of Slavery, March 1, 1780. The Acts of the General Assembly of the Commonwealth of Pennsylvania 282-87 (M'Kean ed. 1782 \& photo. reprint 1984).

31. The Maryland Gazette published a lengthy attack on slavery in May of 1783 which began, "To a people whose characteristic virtues are justice, in the exercise of which they have become the wonder and astonishment of the universe, We, the black inhabitants of these United States, humbly submit the following address." The author, calling himself "VOX AFRICANORUM," wrote, "Though our bodies differ in colour from yours; yet our souls are similar in a desire for freedom. Disparity in colour, we conceive, can never constitute a disparity in rights. Reason is shocked at the absurdity! Humanity revolts at the idea!" The address relied on Revolutionary rhetoric of the enslavement of America to Great Britain and on the Declaration of Independence. "A people who have fought-who have bled-who have purchased their own freedom by a sacrifice of their choicest heroes-will never continue the advocates for slavery." The Maryland Gazette, May 15, 1783, at 3, col. 1. 
the rising tide of emancipation would radically increase the number of free blacks.

The legislature in 1783 faced a society in the grip of social change, particularly in racial relations. Perpetuation of the existing order required new initiatives. The dilemma was to reconcile old principles with a new situation. The prohibition on slave importation prevented blacks from becoming a larger percentage of the total population. The growing antislavery movement, however, threatened to increase the proportion of blacks who were free. The legislature could not prohibit masters from freeing their slaves because a ban on emancipation would invade the property rights of masters as well as offending the antislavery movement. If freedom meant citizenship, the domination of the white establishment would diminish. On the other hand, denial of citizenship to free blacks threatened the principle of vested rights.

The legislature's solution was section 3 of the 1783 law entitled "An Act to prohibit the bringing slaves into this state," which provided that slaves would not acquire the rights of freemen if they were subsequently freed:

[N]o slave manumitted agreeable to the laws of this state, or made free in consequence of this act, or the issue of any such slave, shall be entitled to the privilege of voting at elections, or of being elected or appointed to any office of trust or profit, or to give evidence against any white person, or to enjoy any other rights of a freeman, other than to hold property, and to obtain redress in law or equity for any injury to his person or property. ${ }^{32}$

The statute did not affect the rights of any person who was free when it was enacted, strongly suggesting that the legislature believed blacks who were then free had vested interests that must be respected, including the right that their children succeed to those rights. It also suggests that Taney was simply wrong in asserting that the framers of the Constitution believed that negroes had no rights that the white man must respect. ${ }^{33}$

The creation of a separate class of free blacks who were not citizens prevented blacks from becoming a larger percentage of the citizenry. It preserved the existing community of citizens from change by forces that were expanding the size of the free black class and changing its characteristics. Without invading vested rights or threatening the abolition movement,

32. 1783 Md. Laws Apr. Sess. ch. $23, \S 3$. The prospective structure of the Act is not crystal clear from its language, but the codification of 1796 spelled out the implications by specifying "no slave manumitted agreeably to the laws of this state since the passing of the act, entitled, An act to prohibit the bringing slaves into this state, or made free under the said act ... 1796 Md. Laws ch. 67, \$5.

33. Indeed, one reason for respecting the rights of the free black was that the proslavery argument was based on the sanctity of vested rights. It is difficult to find supporters of slavery in the revolutionary period who argue on the abstract moral issue of slavery. The crucial argument in support of slavery is that slaveholders invested heavily on the faith of existing law so that abolition would deprive them of lawfully acquired property. If historically free blacks were deprived of the rights they had under existing law, it would undermine the justification for slavery itself. 
the proviso in 1783 forestalled any major change in white dominance of the power structure.

There were precedents in neighboring Virginia as well as ancient Greek law for treating freedmen as a class separate from both slaves and citizens. ${ }^{34}$ Maryland's innovation was to make that status depend on timing. Possibly, the legal status of slaves to be freed was considered a matter of policy similar to the status of aliens within a community. As slaves they were not now members of the community, so the community could set the terms on which they would be permitted to remain. No special laws on their status accompanied the statute. Presumably, the impact of the proviso was to exclude slaves emancipated after 1783 from any participation in the political community without otherwise affecting their rights to life, liberty, and property.

When the Constitution of the United States was drafted in 1787, blacks in Maryland could be divided into at least three distinct statuses. Slaves encompassed over ninety-two percent of all blacks in the state. They had no legal rights. Newly Free Blacks, persons freed after 1783 or who claimed their freedom through an ancestor freed after 1783 , constituted a second status, that was tiny in 1787 but certain to grow larger. Newly Free Blacks had property rights and could maintain their rights in the courts, but they were barred from normal incidents of membership in the community such as voting, serving in public office, testifying in cases involving whites, and serving on a jury. Historically Free Blacks, negroes and mulattoes who were free prior to 1783 or who claimed their freedom through an ancestor who was a free person prior to 1783 , were the most privileged. They had most of the rights of white citizens of Maryland. Within the category of Historically Free Blacks, those with white ancestors were also able to testify in cases involving whites. ${ }^{35}$

The law of 1783 could never be a permanent resolution. The existence of free blacks who were not citizens subverted free black citizenship. Personal characteristics of black citizens and non-citizens were the same. Both had an ancestor in slavery. A distinction in fundamental rights dependent solely on an accident of timing was difficult to maintain. The distinction appeared even more arbitrary as 1783 grew more remote, and as successful petitions for freedom after 1783 blurred the significance of the date itself.

34. See T. Wiedemann, Greek and Roman Slavery 45 (1981) on Greek law. Virginia excluded free blacks from voting, $3 \mathrm{~W}$. Hening. The Statutes at large: Being a Collection of all the Laws of Virginia, from the First Session of the Legislatures in the Year 1619 250-51 (1323), $8 \mathrm{id}$. at 307, and $9 \mathrm{id}$. at 114. Under colonial laws still in force, blacks were barred from testifying against whites, 4 id. at $327-28 ; 5$ id. at 245 . Thus Virginia did not face the same issues as Maryland when Virginia became the first state to ban the importation of slaves. See 9 id. at 471 ("an act for preventing the farther importation of Slaves").

35. Legal redress was available in fact as well as theory at least in clear cases. For example, a jury in 1786 found that a free mulatto was wrongfully and violently ousted from her land, and she was awarded punitive damages for the tort in 1787. Mulatto Joan v. Shield's Lessee, 3 H. \& McH. 7 (Md. 1793). 


\section{IV. "Entitled to the Privileges of Citizens"-The Codification of Laws on Race (1796)}

Historically Free Blacks retained their status as citizens when the General Assembly passed "An Act Regarding Negroes" in 1796. ${ }^{36}$ This statute served as the basic law of the status of blacks in Maryland as the eighteenth century drew to a close. It revised and incorporated in a single statute the law of 1783 and statutes passed in 1790 and $1791 .^{37}$

The 1790 statute marked the peak of the drive for the abolition of slavery. It (1) repealed an earlier prohibition on manumission by will, (2) repealed the imposition of servitude on children of interracial unions, (3) punished persons who transported a free negro out of state against his will, (4) punished masters who failed to provide adequate food, clothing and shelter for slaves who could not be lawfully manumitted because they were too old or ill, and (5) punished masters who permitted such "superannuated" slaves to wander at large and become "burthensome" to the neighborhood. ${ }^{38}$

In 1791 white society reacted against the abolition drive. The French Revolution was declining as an inspiration for the spirit of freedom; instead, French internal strife became a symbol of the dangers of revolutionary change. Reports of racial conflict in Santo Domingo made white Marylanders uneasy. ${ }^{39}$ A committee of the House of Delegates condemned the Quakers, the Society for the Abolition of Slavery and others for bringing petitions that would harm slaves by destroying "that spirit of acquiescence among our slaves, by which alone their happiness can be secured, and to inspire them with regret and anxiety for evils that do not admit of a remedy." ${ }^{40}$ Responding to what they found to be an abuse of process in a

36. 1796 Md. Laws ch. 67.

37. 1783 Md. Laws Apr. Sess. ch. 23; 1790 Md. Laws ch. 9; 1791 Md. Laws ch. 75.

38. 1790 Md. Laws ch. 9.

39. See The Maryland Gazette, Dec. 23, 1790, at 2, col. 1 (correspondent's report of insurrection of mulattoes and free negroes who "demand to have the same rights and privileges as the whites, and that they shall be as eligible to hold any office"); id., Sept. 29, 1791 (reports of general uprising at Cape Francois and massacre of whites); The Maryland Journal and Baltimore Advertiser, Jan. 6, 1792, at 2 (report of the destruction of Port au Prince-“The cause of the above disaster is traced to the decree of the National Assembly, declaring the free Mulattoes and Blacks free citizens, and the revocation of the decree.").

40. VPMHD (1791), supra note 15 , at 31 . 
petition-for-freedom suit brought by the Baltimore Society for the Abolition of Slavery, ${ }^{41}$ the Maryland General Assembly passed a law imposing more restrictive procedures in petitions for freedom. ${ }^{42}$

Despite the unsympathetic turn of events in 1791 , the 1796 codification included some measures that improved the position of the free negro. The new law deleted the language of the 1783 Act stating that persons freed after the date of the Act should have none of the rights of a freeman except the rights of property and suit. ${ }^{43}$ Instead, it denied Newly Free Blacks only the rights to vote, to serve in public office, to give evidence against a white person, or to be recorded as competent evidence to manumit any slave petitioning for freedom. ${ }^{44} \mathrm{~A}$ new section protected against the importation of a person bound only for a term of years who was then sold in Maryland as a slave. ${ }^{45}$

Sections 12 through 19 of the 1796 Act were derived from the statute of 1790 . The codification added sections to prevent slave escapes. For

41. The House received a complaint from two Maryland slaveholders, Ezekiel and Edward Dorsey, against the Baltimore Society for the Abolition of Slavery. The Society had filed petitions for freedom in $\mathbf{1 7 9 0}$ on behalf of two Indian slaves who came to Maryland from Pennsylvania. Their exact origins were not easily discovered, because their mother had passed through several hands in Pennsylvania and was in New York at the time of the petition. In November of 1790 , the slaveholders pressed for a trial but the petitioners, not yet ready to proceed, dismissed the case rather than risk losing. Petitioners then filed new petitions in January and were able to bring evidence from Philadelphia for trial at the March term of the court. The slaveholders then asked for a postponement to go to Pennsylvania to collect rebuttal evidence. Returning with evidence to counter the credibility of the petitioners' witnesses, the defendants were ready for trial. Petitioners, however, had yet another witness to obtain; when delay was refused, they once more dismissed the petition and brought a new one. The Dorsey brothers then went to the legislature, complaining that they had incurred expenses in traveling to New York, Pennsylvania and New Jersey to attend the execution of commissions to obtain testimony which exceeded the value of the slaves, and that under existing law they had not received costs for the dismissed suits before new suits were filed.

The House passed a resolution condemning the behavior of the Maryland Society for the A.bolition of Slavery. VPMHD (1791), supra note 15, at 106. The House voted 48-15 that "the said society, in the part they took in support of the said petitioners, have conducted themselves in a most uncandid, unjustifiable, and oppressive manner, and their conduct cannot be justified upon any principle by which good citizens ought to be actuated." See The Maryland Journal and Baltimore Advertiser, Feb. 10, 1792, at 1, col. 1 (report of Committee of Grievances of General Assembly and reply of the Society).

42. 1791 Md. Laws ch. 75.

43. 1783 Md. Laws Apr. Sess. ch. 23, §3.

44. $1796 \mathrm{Md}$. Laws ch. 67, §5. The specification concerning evidence on manumission may have been a direct response to the controversial petitions for freedom against the Dorseys. See supra note 41 . The Dorseys claimed that the evidence produced by the two Indians who petitioned for their freedom was incompetent because their witnesses had been slaves.

45. Id. \$6. The prohibition on importation of slaves did not apply to servants for a term. The punishment for "kidnapping" applied to transportation out of state. See id. §7. Enslavement of a person who was not a slave by the laws of the state from which he came violated the 1783 statute, but no punishment was provided. Thus there was a gap in the law that this section was designed to remedy. 
example, the statute prohibited giving or selling to slaves a certificate of freedom or a pass to enable them to escape. ${ }^{46}$ The new law also extended the prohibition of masters permitting slaves to wander at large and become burdensome on the neighborhood to refer to all slaves and not just those too old or infirm to work. ${ }^{47}$

Sections 21 through 28 re-enacted the restrictions on petitions for freedom as they had been amended in 1793 to provide that such suits could be brought only in county court, and that they would be tried by a jury which would have the final determination of facts. ${ }^{48}$ The last sections (29 through 30) of the statute, drawn from a surviving colonial statute, specified that the process for granting freedom to a slave by deed required the signatures of two witnesses, an acknowledgment by the justice of the peace and the recording of the deed. ${ }^{49}$

Senate amendments shaped the final form of the Act making the law much harsher for slaves. The Senate amended the prohibition on the manumission of "disabled and superannuated" slaves by lowering the age at which a slave was too old to be freed from fifty to forty-five. ${ }^{50}$ The law punishing masters for failing to provide food, shelter, and clothing for slaves ineligible for manumission was omitted. ${ }^{51}$

The Senate also succeeded in obtaining an amendment designed to control free blacks. It prohibited any free negro, mulatto or other person from "living idle, without any visible means of maintenance, or going at large through such county and without any visible means of subsistence." 52 Persons arrested for vagrancy under this statute were required to post a thirty dollar bond or leave the state. Failure to comply resulted in imprisonment. Failure to pay prison charges within twenty days led to sale into servitude for a period up to six months. ${ }^{53}$ The statutory language was general, but the specification "negro, mulatto" before adding "or other person," and the placement of the clause in "An Act Regarding Negroes" demonstrates the expectation that this law would be enforced primarily against free blacks.

The House acceded to all these amendments. One other Senate proposal, however, was unacceptable. The Court of Appeals had been very sympathetic to petitions for freedom and its recent evidentiary rulings had

46. Id. $\$ \$ 18-19$.

47. Id. $\$ 17$.

48. Id. \$§21-28. See 1793 Md. Laws ch. 55; 1791 Md. Laws ch. 75.

49. 1796 Md. Laws ch. $67, \S \S 29-30$. See 1752 Md. Laws June Sess. ch. 1.

50. VPMS (1796), supra note 16 , at 47.

51. Id. This is the effect of the strikes on the eleventh and twelfth pages of the bill as may be deduced by comparing the 1790 law with section 17 of the 1796 statute. The language of the 1790 law acknowledging the justice of remembering the faithful service of the slave was a casualty of this deletion.

52. Id.

53. 1796 Md. Laws ch. $67, \S 20$. 
proved helpful to petitioners. As a result, a number of successful petitioners were able to testify in the petitions for freedom of others who claimed to be their relatives. ${ }^{54}$ This prompted the Senate to attempt to prohibit the use in such petitions of testimony from any person held as a slave who had subsequently been adjudged free. ${ }^{55}$

The House refused to accept this amendment:

GENTLEMEN OF THE SENATE

We have dissented from your first amendment . . . We cannot agree to this amendment, because it goes to the competency of witnesses born of free ancestors, and entitled to the privileges of citizens. We think that the credibility of such persons ought always to rest with the jury of their country. ${ }^{56}$

The Senate receded from this amendment, and the Act Relating to Negroes of 1796 was passed. ${ }^{57}$

Despite the harsh changes against slaves and the stirring of reaction against free blacks, in 1796 the House of Delegates recognized the citizenship of Historically Free Blacks, at least those like Benjamin Banneker who vere born of free ancestors.

54. For example, the law permitted enslavement of a child bom of a white woman who married a black man between 1664 and 1681 . A number of mulattoes were held in slavery for generations, presumably on the basis that their white ancestors were subject to this law. In 1783 the Court of Appeals found that a daughter could obtain freedom although her mother had been adjudged a slave. The prior judgment was not res judicata on the daughter and the evidence from that trial was not permitted in the subsequent case because the daughter was unable to cross-examine. As a result, there was no proof that the petitioner's white ancester married a slave during the period in question. Because the daughter could show descent from a white woman, she obtained her freedom. Toogood v. Scott, 2 H. \& McH. 26 (Md. 1783). This decision opened the door for the Toogood and Fisher families to claim freedom. In 1791 the Court of Appeals reached a similar result which opened up the path to freedom for the Butler family. Butler v. Craig, 2 H. \& McH. 214 (Md. 1791). Although the petitioner was unable to testify on her own behalf, once freed she could testify in favor of others. In 1794, decisions on petitions for freedom cleared the way for the Shorter family and the Thomas family. Shorter v. Rozier, 3 H. \& McH. 238 (Md. Gen'l Ct. 1794); Thomas v. Pile, 3 H. \& McH. 241 (Md. Gen'l Ct. 1794).

Another evidentiary ruling that favored freedom was the admission of hearsay evidence. Defending a slaveowner in a petition for freedom, attorney Luther Martin admitted: "Our courts have determined that general reputation, that such persons are descended from white persons, or that they have exercised the right of freedom, is evidence to the jury." Mahoney $v$. Ashton, 4 H. \& McH. 295, 312 (Md. 1797). This principle had been applied in Toogood and was upheld in Mahoney, although the Court of Appeals ultimately held that the petitioner's evidence was insufficient as a matter of law.

55. "And be it enacted, That no negro or mulatto heretofore or hereafter held in bondage, and claimed as a slave, but who has been or hereafter may be adjudged free, as descending from a free ancestor, nor the descendants of any negro or mulatto so manumitted or adjudged free, shall be received as competent evidence to manumit any slave petitioning for freedom." VPMS (1796), supra note 16, at 47 . The word "no" was originally printed as "any", but a subsequent errata sheet corrected it.

56. VPMHD (1796), supra note 15, at 110. The vote was 16-30.

57. VPMS (1796), supra note 16, at 53. 


\section{Deprivation of Political Rights: The Legal Status of the Free Black in 1801-Disenfranchised and Debased}

The most important legal development affecting blacks during the half decade following the codification of the Act Regarding Negroes was the movement to abolish the property qualification for voting. ${ }^{58}$ Ironically, the movement for "universal suffrage" led to the disenfranchisement of Historically Free Black voters. That disenfranchisement was a crucial step in the legal degradation of the free black.

\section{A. Disenfranchisement in the "Democratizing" Amendment of 1801-02}

The movement to abolish property qualifications first appeared in the proceedings of the General Assembly in 1792, when the Assembly convincingly defeated a motion to amend the constitution to confer suffrage on all white male citizens who met age and residence requirements. ${ }^{59}$ The issue stayed out of the legislature until 1797 when Michael Taney, Roger Taney's father, introduced a bill to abolish the requirement of property as a qualification for voters. ${ }^{60}$ The House amended the bill with Michael Taney's support to state:

58. In the five years following the 1796 Act Relating to Negroes which codified race related laws, a few minor amendments to the statute were adopted. One amendment made it clear that the legal representatives of citizens moving into the state could exercise the rights of the citizens they represented to bring slaves with them into the state. $1797 \mathrm{Md}$. Laws ch. 15. Another permitted residents with property in both Maryland and adjoining states to transfer slaves between the properties. 1798 Md. Laws $\mathrm{ch}$. 76.

59. The issue had been raised in the initial Constitutional Convention of 1776, but remained quiet for the next decade and a half. In the wake of the conflict over France's extension of voting rights to the free mulattoes of Santo Domingo, an abortive proposal to exclude Historically Free Blacks from the franchise was made in 1791. House committee proposals to amend the state constitution included a clause disenfranchising black voters.

VII That no negro or mulatto, whether born free or manumitted, or made free under any past, present, or future law of this state, and no issue of such negro or mulatto, shall be entitled to the privilege of voting at any election, or of being elected to the legislature or council, or as an elector of the senate, or of being appointed to any office whatsoever.

The Maryland Gazette, March 22, 1792. Although the proposals were printed for public information, they were not even voted upon in the House.

The issue of abolition of property qualifications for the franchise was raised the following year.

The following question being propounded to the house, viz.

"That leave be given to bring in a bill giving the right of suffrage only to every white male citizen (and not a menial servant) being the age of twenty-one years, and having had residence twelve months preceding any election at which he may offer to vote, and that any part of the constitution contrary thereto shall be repealed and made void?" Defeated 13-43

VPMHD (1792), supra note 15 , at 89.

60. VPMHD (1797), supra note 15 , at 57. 
Be it enacted, by the general assembly of Maryland, that all free born men above the age of twenty-one years, and having resided in the county in which they offer to vote one whole year next preceding the election, shall have a right of suffrage at all elections to be held in the county in which such free born man shall have so resided. ${ }^{61}$

The bill focused on eliminating property qualifications, but it signaled a shift in the distinction among groups of free blacks. It substituted status at birth for status in 1783. The extension of the vote to "all free born men" excluded those Historically Free Blacks emancipated prior to 1783, but it would have extended the vote to the free born children of Newly Free Blacks. In the short run this would reduce the pool of blacks who could take advantage of the elimination of property qualifications for voting, because no child of a Newly Free Black would be eligible to vote until 1804 . Until that date, the distinction between freeborn blacks and freed blacks roughly approximated the statutory distinction for practical purposes (to the disadvantage of those Historically Free Blacks who had been freed prior to 1783). The use of status at birth instead of status in 1783 in the bill may have reflected common usage. In any event, the racial impact of the statute did not seem central to objections, and the bill passed the House 30-21. ${ }^{62}$ The Senate, unready for universal suffrage, rejected the bill. ${ }^{63}$

In the heat of the House debate, Joseph Nicholson "moved to enlarge the right of voting to 'women and children,' intimating thereby, that the proposition was so unreasonable, as to be entitled only to be treated with ridicule." 64 Six years later, with the benefit of hindsight, Nicholson denied that he had ever opposed the abolition of property requirements. He claimed that he opposed the bill of 1797 because it included blacks as well as whites and he thought the experience of Santo Domingo showed the dangers in black voting. ${ }^{65}$

Nicholson may have been disingenuous about the reasons for his behavior in 1797, but he consciously focused on the racial impact of suffrage proposals by the next year. In 1798 Nicholson brought in a committee bill "so framed as to give the right of suffrage to all free white citizens." 66 Over the objections of Michael Taney and Nicholson, the House voted to postpone consideration of the bill until the next session. ${ }^{67}$ In that next session Roger Brooke Taney, newly admitted to the bar just that

61. Id. at 96 .

62. Id.

63. VPMS (1797), supra note 16 , at 38.

64. 2 J.T. Scharf, History of Maryland 609 (1879 \& reprint 1967).

65. Eastern Shore General Advertiser, Sept. 20, 1803 (letter from Joseph H. Nicholson).

66. See id. VPMHD (1798), supra note 15 at 71.

67. VPMHD (1798), supra note 15 , at 83. 
spring, replaced his father in the House of Delegates. Roger Taney supported the suffrage bill which presumably embodied his father's proposal in the racially exclusive language drafted by Nicholson and his fellows. ${ }^{68}$ The bill died in the Senate. ${ }^{69}$

Records from the election of 1800 illustrate the racial effect of the franchise laws then existing. In the city of Annapolis, the election judges kept a record of the objections made to each individual voter and how they were resolved. Annapolis was unique, because its qualifications for voting for delegate were based on the city charter, while the property qualifications were spelled out in the State Constitution for all the counties and Baltimore City. ${ }^{70}$ The differences, however, did not relate to race.

Over 300 city residents tried to vote. Approximately twenty negroes or mulattoes applied to vote and fifteen were accepted. Many voters faced challenges for failure to meet the property requirements, but the election judges accepted the voters who stated under oath that they possessed sufficient property. The basic distinction between those permitted to vote and those denied was whether they were born free or had been emancipated. ${ }^{71}$ In summary, the Annapolis election of 1800 demonstrated that free born blacks with sufficient property did vote, and that Newly Free Blacks were barred.

One reason for black voter turnout in the Annapolis election of 1800 may have been an awareness that black voting rights were at stake. That fall the House of Delegates again considered a bill to abolish property requirements and give the vote to free white men. On the second reading of the bill, "the question was put, That the word "white' be stricken out of the said bill?" 72 The motion went down to a crushing 16-51 defeat. John Johnson,

68. VPMHD (1799), supra note 15 , at 34.

69. VPMS (1799), supra note 16, at 9.

70. Anderson, Eighteenth Century Suffrage: The Case of Maryland, 76 Md. Hist. Mag. $141,143-44$ (1981) (discussing voting qualifications in Maryland and the effect of the differences between those for Annapolis and the rest of the state).

71. Annapolis, Poll taken October 6, 1800 for delegates to represent the city. Maryland Hall of Records, Annapolis, Maryland.

Racial challenges were noted as challenges based on birth rather than as challenges based on freedom prior to 1783; but on a line cramped for space to note objections, "birth" could have been a shorthand for the more precise legal standard. The poll book notations are not conclusive on the actual standard applied. There is no indication on whether any of the persons denied the vote because they were not born free had been freed prior to 1783 . The statutes point to eligibility, but the election judges did not use statutory language in noting their decisions. See Bogen, supra note 24.

72. VPMHD (1800), supra note 15 , at 51 . 
the Annapolis delegate most black voters had supported, cast his vote to eliminate racial exclusivity, but his was a lonely voice. ${ }^{73}$ The House of Delegates passed the bill for white suffrage, but the gap between the views of the House of Delegates and the Senate on property qualifications frustrated enactment once more. ${ }^{74}$

The election in 1801 emphasized the franchise proposals and the conflict over property requirements. Supporters of repeal of the property qualification succeeded in the election and, consequently, in the General Assembly. Thus, the General Assembly passed a law in 1801 to amend the state constitution as follows:

That every free white male citizen of this state, and no other, above twenty-one years of age, having resided twelve months in the county next preceding the election at which he offers to vote, and every free white male citizen of this state above twenty-one years of age, and having obtained a residence of twelve months next preceding the election in the city of Baltimore or the city of Annapolis, and at which he offers to vote, shall have a right of suffrage, and shall vote by ballot in the election of such county or city, or either of them, for delegates to the general assembly, electors of the senate and sheriffs. ${ }^{75}$

73. Id. See also Bogen, supra note 24. At least five of the sixteen who voted in favor of striking "white" from the bill were opposed to the abolition of property requirements. The entire Somerset delegation (Lowes, Hyland, Dashiell and Holbrook) and Delegate Purnell from Worcester voted to require voters to have a personal estate of thirty pounds. VPMHD (1800), supra note 15 , at 51 . This suggests the possibility that their support of the motion to eliminate racial references was a gambit to weaken the bill rather than a principled stand.

74. After the House of Delegates passed a bill to amend the state constitution with respect to voter qualifications, the Senate proposed a requirement that the elector have been taxed. VPMS (1800), supra note 16 , at 28-29. The House rejected the amendment, noting that

$[\mathrm{M}]$ any men, who are now under the constitution entitled to the right of suffrage, will then be excluded, because many individuals possess the sum of thirty pounds who are not, nor cannot, agreeable to law, be assessed at all; then so far from extending the privileges of voting, it will tend to curtail it and the object of the bill destroyed.

VPMHD (1800), supra note 15 , at 74 . The Senate claimed that because the requirement of $\operatorname{tax}$ assessment had no currency limit, it was more liberal than the existing 50 acre or 30 pound requirement. The Senate then said, "The power of deprivation has been exercised by you in the first part of your bill, to an extent beyond which it was not our design to carry it." VPMS $(1800)$, supra note 16 , at 43 . The reference to deprivation may have been to the House bill's exclusion of Historically Free Black voters. After some further volleys between the House and Senate, the Senate defeated the proposal with a remark showing that it was not opposed to the restrictive portions of the House proposal.

We did not say that we meant not to exclude any person now constitutionally entitled to suffrage. Our assertion was, that you had exercised, in the first part of your bill, the power of deprivation to an extent beyond which we did not design to carry it. In this position we conceive ourselves to have been correct, as we are well assured there is not a citizen in the state possessing thirty pounds worth of property, in the meaning of our present constitution, who might not, under the operation of our amendments, be admitted to the right of suffrage.

Id. at 48 .

75. 1801 Md. Laws ch. 90 (emphasis supplied). 
Upon the amendment's confirmation in 1802, the Maryland State Constitution denied all blacks the right to vote. ${ }^{76}$

The egalitarian ideal underlying the movement for universal suffrage stressed the equality of all whites at the expense of the race which they regarded as inferior. ${ }^{77}$ Further, unless blacks were disenfranchised, the abolition of the property requirement would have enfranchised proportionately more blacks than whites, because free blacks had less property than whites. Finally, the elimination of the property test diluted the control of the propertied voter and thus undermined arguments based on the vote as a vested right.

In addition to these factors, which were common to all states, several other factors peculiar to Maryland may have contributed to disenfranchisement. First, the eligible voter had become an anomaly among free blacks. The 1783 law accepted the proposition that free blacks ought to be excluded from voting, but preserved the rights of those already eligible to vote. As a result of continued manumission, Newly Free Blacks now supplanted Historically Free Blacks as the predominant group of free blacks. ${ }^{78}$ The special treatment afforded the Historically Free Black increasingly was in

76. $1802 \mathrm{Md}$. Laws ch. 20. The Constitution could be amended by the adoption of an amendment by two successive legislatures. There has been a continuous confusion over the effective date of this amendment, because it was subsequently amended in 1810 with respect to residency provisions. See Bogen, supra note 24.

77. Edmund Morgan suggested that the subordination of blacks as slaves in colonial Virginia encouraged an ideology of republican equality-i.e., all whites were alike when contrasted with slaves. E. Morgan, American Slavery-American Freedom 380-81 (1975). The idea of racial inferiority works equally well as slavery as the foil for egalitarianism of whites. But this factor was not a major overt argument. "The union of pro-slavery and suffrage democracy as a deliberate policy did not develop until 1829." C. Williamson, American Suffrage from Property to Democracy, 1760-1860 232 (1960).

78. There were 8043 free blacks in 1790 , a figure which must have included a number of persons freed during the previous seven years. J. Wright, supra note 9 , at 92 . There were about 2000 free blacks in Caroline, Dorchester and Talbot counties in 1790, about one-quarter of the total free black population of the state. Carroll, supra note 15, at 177. Almost 1000 slaves had been freed in those three counties between 1783 and 1790 . Quakers freed 150 slaves in those counties between 1782 and 1791 . Id . at 183. At least 834 slaves were freed by others in those same counties between 1783 and 1790. Id . at 191. When manumissions from other counties and the cities are added to this total, it would appear that a substantial proportion of the free black population of 1790 had been manumitted after 1783 .

By 1800 the free black population had increased by more than 11,000 to $19,587 . J$. Wright, supra note 9, at 88. This stupendous growth cannot be attributed to the birth rate. Most of the growth in the free black population came from emancipation, although immigration from neighboring states may have contributed. Once more, nearly a quarter of the free black population resided in Caroline, Dorchester and Talbot Counties (4558). The growth of the free black population in those counties, from 2000 to 4558 , included 999 slaves who were recorded as being freed by deeds of manumission between 1791 and 1799. Carroll, supra note 15, at 191. Another group of slaves were freed in these counties by family members who purchased and then freed them. Still more slaves were freed by will after 1790. Thus, the majority of free blacks in 1800 had been freed after 1783. 
tension with the general principle excluding free blacks from participation in government.

Second, the division between Historically Free Blacks and Newly Free Blacks was breaking down. The controversy in 1796 over the admission of testimony of Historically Free Blacks revealed that many blacks held in bondage were obtaining freedom on grounds that made them "Historically Free Blacks." Thus, men voted who had secured their freedom in the courts rather than from manumission, although they had been held in slavery after $1783 .{ }^{79}$ This may have undercut acceptance of the division made in 1783 between Newly Free Blacks and Historically Free Blacks.

Voting rights were not universally accepted rights in the society. The franchise was, as the Maryland Senate had said in 1800, a right framed by society and not a natural right. ${ }^{80}$ Even proponents of the abolition of property qualifications for the franchise assumed that women could be denied the vote without being excluded from citizenship. Thus, there was less concern over the right to vote than for such other vested rights as life, liberty, or property.

Nevertheless, the deprivation of any right weakens the broader principle that vested rights may not be taken. The exclusion of blacks from political participation made their exclusion from other rights less shocking. Finally, arguments for universal suffrage identified voting with the rights of man and blurred the distinction between political privileges and civil rights.

\section{B. Admission of Slave Testimony Against Free Blacks in Theft Cases}

In 1801 the Maryland House of Delegates attempted to prevent "persons of colour" from being competent witnesses for or against whites in specific cases. ${ }^{81}$ The text of the bill passed by the House was not given in the House Journal; but, because the 1796 Act excluded the testimony of Newly Free Blacks against whites and in manumission cases, this new

79. This was demonstrated in the Annapolis election of 1800 . Seven of the 15 black voters were members of families freed in petitions of freedom after 1783. See Bogen, supra note 24.

80. In urging universal suffrage, the Maryland House of Delegates had stated: "when we reflect that liberty is the common and natural right of all men, we cannot agree to sanction that doctrine which makes property the measure of it." $V P M H D(1800)$, supra note 15 , at 89 . The Senate responded: "But we do not consider natural liberty, and the right of suffrage, as the same thing. The latter is an adventitious right, derived not from a state of nature, but society." VPMS (1800), supra note 16 , at 48 . All men were entitled to natural rights, but suffrage could be limited in the interests of the society.

81. VPMHD (1801), supra note 15 , at 112 . 
proposal must have been an attempt to extend the exclusion in some manner to Historically Free Blacks. ${ }^{82}$ Such an extension in the disenfranchisement year would have been consistent with the linkage of testimony and voting in 1783, and passage of the bill would have gone far to destroy all remaining distinctions among free blacks. The distinctions were preserved, however; because the Senate rejected the bill. ${ }^{83}$

Although the Senate rejected the House bill to exclude the testimony of blacks in cases involving whites, it proposed its own evidentiary statute. It revived a nine year old proposal to permit slave testimony in order to convict free negroes of violating the law that prohibited dealing with slaves without license from their master. ${ }^{84}$ Although no statute specifically excluded evidence of slaves in cases involving free negroes, it may be in-

82. The bill was probably a revised version of the bill the House itself defeated in 1796. One factor in its revival may have been the recognition that the testimonial exclusion of 1717 was tied to the period of servitude by law, and that law's effect was altered when the legislature abolished the imposition of servitude on children born of an interracial relationship. $1790 \mathrm{Md}$. Laws ch. 9, §4. Although free negroes may already have been prevented from testifying in cases involving whites, see supra note 20 , a mulatto born of a white woman could testify. The petition for freedom cases also demonstrated that persons claiming freedom through descent from a white woman, no matter how many generations earlier, could testify.

83. VPMS (1801), supra note 16 , at 56.

84. In 1792 the House struck from a bill by a vote of 30-27 the following proposal:

And, whereas the citizens of this state experience very great inconveniences from free negroes dealing with slaves, whereby very great inducements are held out to slaves to pilfer and steal, and the secret mode of carrying on such dealing and correspondence renders it almost impossible to obtain the testimony of white persons to convict such free negroes of the offences aforesaid, whereby they go unpunished for the same, $\mathrm{Be}$ it enacted, That any slave or slaves, above the age of fifteen years, may, at any time hereafter, be received and admitted as a witness, to convict any free negro of dealing as aforesaid with any slave or slaves contrary to the provisions of this act, and such testimony shall be as good and available in law, for the purpose aforesaid, as the testimony of a white person any law heretofore passed to the contrary notwithstanding; and if any free negro, who shall be convicted of dealing with any slave or slaves as aforesaid, shall be unable to pay the fine of three pounds aforesaid, the justice, before whom such free negro shall be convicted, shall have full power and authority to sentence such free negro to work at the rate of-per day for the master or owner of such slave until the said sum of three pounds is fully paid and satisfied.

VPMHD (1792), supra note 15 , at 98 . 
ferred from these proposals that the courts had excluded slave testimony in cases involving free persons of any race. ${ }^{85}$ As legislators had stated almost a decade before, it was difficult to prove a free negro had obtained fungible goods illegally from a slave without permitting the slave to testify. Masters perceived the loss of their possessions to be an increasingly serious problem as the free black population grew. In 1801 the General Assembly enacted the new law admitting slave testimony both for and against a free negro or mulatto who was charged with stealing goods or receipt of stolen goods. ${ }^{86}$

This new law now affected the basic civil rights of a free black, permitting the deprivation of liberty with evidence not admissible against a white defendant. It provided one more token of the degradation of the status of the free black. It also treated all blacks alike, whether negro or mulatto, whether Historically Free Blacks or Newly Free Blacks, accelerating the dissolution of those distinctions.

\section{Deprivation of Civil Rights: The Legal Status of Free Blacks in 1805-Sacrificed to the Control of Slavery}

With their total exclusion from the political community, free blacks becarne subject to racial legislation intended to resolve particular social problems identified by the legislature. Free blacks, especially the majority who had relatives still in slavery, were perceived to be far more likely than whites to sympathize with slaves and aid them in escaping or in taking goods from their masters. It was difficult to prove specific acts of assisting escapes or receiving stolen goods, so the general laws of prohibition seemed inadequate. The legislature was tempted to enact more rigorous laws, but a general application of such laws would have conflicted with the interests of white citizens. This led to enactments restricting free blacks to prevent them from assisting slaves in acts of rebellion against the masters. The set of laws made blacks even more clearly a distinct and disadvantaged group. Whites perceived the denial of basic rights of movement, speech, trade, and other forms of participation in society as necessary to protect slavery, but it was obviously incompatible with the recognition of blacks as members of a common community.

85. Slaves, free negroes and mulattoes born of white women during their period of servitude by law were barred from giving evidence in cases involving whites. $1717 \mathrm{Md}$. Laws ch. 13, §2. Since 1783, Newly Free Blacks were barred from testifying against whites and in petitions for freedom. $1783 \mathrm{Md}$. Laws Apr. Sess. ch. 23, \$3; $1796 \mathrm{Md}$. Laws ch. 67, §5. No statute expressly prohibited the use of such testimony against free blacks; statutes only expressly prohibited its use in cases involving whites.

On the other hand, the 1717 statute specifically permitted the use in non-capital cases of testimony of "any negro or mulatto slaves, free negro, mulatto born of a white woman, during their servitude by law, . . . against such negro, mulatto slave etc." 1717 Md. Laws ch. 13, §3. Apparently, courts had interpreted this statute not to apply to slave testimony against free negroes. Probably it was read to allow testimony only of persons of the defendant's status or above.

86. 1801 Md. Laws ch. 109. 


\section{A. Licenses for the Sale of Corn, Tobacco and Wheat}

In 1805 the legislature first required free negroes to obtain licenses of good character for certain activities. The evidence statute of 1801 did not end white property losses. In 1805 the General Assembly attempted once more to deal with losses it considered to stem primarily from free blacks' sale of property from white plantations. The legislature's first thought was to forbid all sales by free blacks. ${ }^{87}$ It then considered imposing a stiff tax on sales by free blacks with an exemption for sellers who obtained a certificate of good character from the county court. Ultimately, the legislature decided to rely wholly on the certificate requirement. ${ }^{88}$ The result was an act requiring any free negro to obtain an annual certificate of good character from a justice of the peace in order to sell corn, tobacco or wheat. ${ }^{89}$

The theory behind this law appears to be that although all persons were entitled to pursue an occupation, a prophylactic licensing requirement was necessary to stop unlawful behavior because subsequent punishment had proved ineffective. One impact of the law was to make free negroes dependent on their white neighbors for permission to ply their trade. This encouraged subservience in free negroes and paternalism in their white neighbors.

\section{B. Certificates of Freedom Regulation}

Fear of slave escapes led to greater restrictions on free blacks in 1805. Blacks could be free by birth, by testamentary manumission, or by deed of manumission. Outside the county where they were known, free blacks needed a document to prove their freedom. Certificates attesting to their freedom might be provided by the clerk of a county court, a judge, or even a former master. No law regulated the issuance of such certificates. The 1796 Act punished transfer of such certificates to persons not entitled to them, but it was hard to enforce. Certificates often did not describe the freed person and a free black could obtain with some effort more than one certificate. In 1805 the law was amended to spell out the details for granting certificates of freedom, requiring a description of the freed person and limiting the authorized issuers, and imposing a penalty on any person granting such a certificate contrary to the statute. The law also provided for

87. Originally, leave was granted to bring in a bill entitled, "An act to prevent free coloured persons from selling wheat, corn, or tobacco." VPMHD (1805), supra note 15, at 17.

88. The committee entitled its bill- "An Act to prevent free negroes from receiving of any slave or slaves any article of provision and selling the same as the production of their own labour." Id . at 64 . The substance of the bill was a requirement that sellers either pay a county tax or obtain a license, and the title was changed on the floor of the House to conform with the bill's substance. In addition, the House struck a clause which made the licensing an alternative to the payment of a county tax, so that the bill sent to the Senate was a flat license requirement. Id. at 80 . The vote was 31-28.

89. The Senate eliminated a vague reference in the bill to "other articles of provisions." $\operatorname{VPMS}$ (1805), supra note 16 , at 38 . The House accepted the amendment. $1805 \mathrm{Md}$. Laws ch. 80. 
certificates for negroes born free so that they could travel out of the county of their birth. ${ }^{90}$ Regulation of certificates of freedom made escape more difficult for slaves, but it also made life more burdensome for the free black.

From the legislature's perspective, the licensing and certificate laws respected the civil rights of free blacks. The laws provided a procedure through which honest, law-abiding blacks could exercise their rights of travel and trade. Nevertheless, the difference in procedures for exercising rights amounted to a different substantive right. When one segment of a community is regarded with such deep suspicion that they must prove their character before being able to exercise basic fundamental civil rights, it is difficult to regard them as members of the community. The "liberty" of the free black could no longer be considered identical to the "liberty" of the white citizen. Now the revolutionary ideal of the equality of man was not only incompatible with slavery, but with the status of free blacks as well.

\section{Loss of Citizenship: The Legal Status of the Free Black in 1806-Prohibited from Immigrating and Restricted to a Single Dog}

The belief that free blacks were members of the political community had been undermined by the creation of separate classes of free blacks in the nonimportation law of 1783 . The 1802 Maryland Constitutional amendment eliminated all free blacks from participation in the political community and facilitated separate treatment in subsequent legislation. The discrimination in the statutes of 1805 prepared the way for a denial that free blacks were even citizens. By 1806 , the General Assembly was prepared to take that step. 91

\section{A. The Law Against the Immigration of Free Blacks}

The immediate impetus for Maryland's behavior was an 1806 Virginia

90. $1805 \mathrm{Md}$. Laws $\mathrm{ch}$. 66 . The new law required the certificate to contain a description of the individual, limited issuance to clerks of county courts where the negro was given freedom, punished other persons issuing certificates and clerks who knowingly (Senate addition of scienter) gave a certificate to one not entitled to it, and provided for certificates for freeborn negroes. The statute was amended in 1807 because of a potential uncertainty when the negro resided in a county different from the one where the will or deed of freedom was recorded. The new statute made it clear that the certificate had to come from the office of the clerk where the deed or will was recorded. $1807 \mathrm{Md}$. Laws ch. 164. The 1796 statute on certificates for freedom carefully distinguished negroes and mulattoes. $1796 \mathrm{Md}$. Laws ch. 67, §18. The 1805 statute which supplemented it did not mention mulattoes. It appears that "free negro" now was understood to include mulatto, perhaps because the legal distinctions were disappearing.

91. In 1806, a 21-30 vote of the House rejected a petition for leave to bring in a bill for the gradual aboliton of slavery. VPMHD $(1806)$, supra note 15 , at 39 . With slavery firmly rooted in the state, the laws slowly closed the gap between the status of slave and that of free black. 
statute prohibiting the manumission of slaves unless the freed slave left the state. ${ }^{92}$ This promised to make Maryland a haven for manumitted Virginians. ${ }^{93}$ As demonstrated by the laws of 1805 , free blacks were not popular with the Maryland General Assembly. It responded to the Virginia law in the very next legislative session.

In 1806 the Maryland General Assembly passed a statute forbidding the immigration of free negroes into the state, fining the illegal immigrant for each week after the second week he stayed in the state, and fining any employer who hired an illegal immigrant. ${ }^{94}$ The vote was overwhelming. ${ }^{95}$ There were numerous reasons why Maryland did not act against free black immigration before Virginia's statute forced the issue, but one of them may have been that the Constitution of the United States guaranteed to the citizens of the several states that they would be afforded the privileges and immunities of citizens in the several states. ${ }^{96}$ That is, citizens of one state were entitled to enter another state and be treated as citizens. A barrier to immigration from another state was therefore the equivalent of a denial that the immigrant was a citizen. But discriminatory laws indicated that the state no longer considered blacks to possess all the privileges of citizens, and that contributed to the willingness to exclude free negroes.

\section{B. The 1806 Licensing Act for Guns and Dogs}

The ease with which discrimination now entered legislation also was manifested in the enactment of a law requiring free negroes to have a license of good character in order to possess a dog or a gun. The legislature

92. Slaves manumitted after May of 1806 were required to leave the state within twelve months. 3 S. Shepherd. The Statutes at Large of Virginia, from October Session 1792, to December Session 1806, Inclusive 252 (1835). Since 1691 Virginia colonial statutes had prohibited masters from freeing their slaves unless the slave were transported out of the'state. 3 Hening, supra note 34 , at $87-88$; see 4 id. at 132 . This raised no significant concern in Maryland because emancipation was rare. As the drive for emancipation increased, Virginia repealed its restrictions in 1782.11 id. at $39-40$. When Virginia returned to the colonial restrictions in 1806, there had been over two decades of numerous manumissions and the immediate impact of the new law was a stream of free negroes entering Maryland from Virginia. I. Berlin, Slaves Without Masters 92 (1974). See T. Tate, The Negro in Eighteenth Century Williamsburg 116, 123-24 (1965).

93. "Virginia has passed a law and many of her beggarly blacks have been vomited upon us." J. Russell, The Free Negro in Virginia 1619-1865 $71 \mathrm{n} .109$ (1913) (quoting petition to the Maryland House of Delegates in Maryland Historical Society portfolio 7, no. 28).

94. 1806 Md. Laws ch. 56.

95. Forty-three to eight in the House. VPMHD (1806), supra note 15 , at 69 . The punishment for employing free negro immigrants may have been the disturbing element for some of the delegates who opposed the new law.

96. U.S. Const., art. IV, §2. 
had expressed concern over the proliferation of dogs for several years. ${ }^{97}$ Apparently dogs were a threat to livestock. ${ }^{98}$ In 1806 the General Assembly passed "An Act to restrain the evil practices arising from negroes keeping dogs, and to prohibit them from carrying guns or offensive weapons." 99 The law completely prohibited slaves from keeping dogs or guns. It limited to one the number of dogs a free negro could own and required a license of good character to possess even that one. The regulation of dog ownership reveals the use of race-specific legislation to deal with a problem that crossed racial lines. The legislature was careful to protect the interests of white dog-owners, but no longer considered the interests of blacks significant in protecting against nuisances.

The bill also displayed the increasing concern of the white community that free negroes would assist in slave revolts. It not only required free negroes to obtain an annual license to keep guns, but it also made it a crime for a free negro or mulatto to be at a "tumultuous meeting" of negroes and slaves. ${ }^{100}$

\section{The End of Distinctions Among Free Blacks: The Legal Status of Blacks in 1810 - The Exclusion of Testimony of a Descendant of a White Woman in Cases involving Whites}

The next major step in the collapse of black rights involved the law of evidence. ${ }^{101}$ The courts demonstrated uncertainty over the status of free black testimony against whites in 1806 . The 1717 statute on testimony in

97. In 1804, Mr. Chapman brought in a bill "to prevent the mischiefs arising from multiplicity of useless dogs in this state." VPMHD (1804), supra note 15 , at 79 . The next year, late in the session, a bill to prevent negroes from owning dogs and guns was presented. It was amended to allow free negroes and mulattoes to possess guns with an annual license from a justice of the peace, but a motion to remove agricultural implements from the category of offensive weapons was defeated. VPMHD (1805), supra note 15, at 117. The Senate rejected this bill. VPMS (1805), supra note 16, at 47 . In 1806 residents of Harford County filed a petition requesting that negroes be prevented from keeping dogs or guns. VPMHD (1806), supra note 15, at 23.

98. See the petition from Baltimore City to decrease dogs and increase sheep, VPMHD (Nov. Sess. 1809), supra note 15, at 66; various petitions referred to a committee which reported on a bill to prevent the destruction of sheep by dogs, VPMHD (1810), supra note 15 , at $49,64,78,81$.

99. $1806 \mathrm{Md}$. Laws ch. 81 .

100. Id. §3.

101. There was a good deal of activity in the legislature between the statutes of 1806 and the decisions of 1810 . It was not, however, of the same dimension as the prior enactments.

Whites continued to lose property and slaves continued to escape despite the laws that had been passed. The General Assembly considered various measures to tighten the existing laws to increase their effectiveness. In 1807, a proposal was made to amend the licensing for free negro sale of com, tobacco and wheat to require two neighbors to make out an affidavit on the amount that could be grown on the free negro's premises, to license sale by a certificate specifying that limited amount, and to require all purchasers to endorse upon that certificate the amount of purchase. VPMHD (1807), supra note 15 , at $28-29$. This system would have 
cases involving whites did not mention mulattoes born of free negro mothers. ${ }^{102}$ In State $v$. Fisher, a criminal trial against a white defendant, a divided trial court admitted the testimony of a mulatto woman born free to a manumitted negro woman. On appeal, the Court of Appeals could not agree in opinion on the question and left the issue undecided. ${ }^{103}$ Although it is difficult to determine the exact significance of the court's division without opinion, the willingness of some judges of the Court of Appeals to

totally prevented free negroes from selling any product they did not grow and would have added a layer of paperwork cumbersome to everyone. It was defeated. Id. at 36.

An attempt to amend the law on certificates of freedom was more successful; an amendment was enacted to make certain that such certificates would only be issued by the clerk in the county where was recorded the deed of manumission or will under which freedom was claimed. $1807 \mathrm{Md}$. Laws ch. 164.

Two bills passed the 1809 session dealing directly with free negroes. The statute on crimes and punishments contained a section punishing free negroes, mulattoes and slaves for conspiring, attempting, or actually raising an insurrection or rebellion in the state and punishing whites who acted with them. $1809 \mathrm{Md}$. Laws ch. 138, §2. The second law dealt with the legal status of children born to slaves who had been manumitted by an instrument that provided the manumission would take effect at a later date. The statute empowered the master to determine the status of the child born after the date the mother's freedom was fixed but before it occurred, but left slavery as the default position. $I d$. ch. 171 .

The legislature in 1810 passed two statutes which dealt with free blacks and determinations of free or slave status. The first statute responded to a Court of Appeals decision that a deed of manumission was ineffective for failure of the witnesses to sign it notwithstanding that the justice of the peace had specifically told the master that such signatures were unnecessary and the deed was recorded. Negro James v. Gaither, 2 H. \& J. 176 (Md. 1807). The new statute provided that recorded deeds of manumission would be valid even if they did not have sufficient witnesses, except as to bona fide purchasers prior to the date of the Act. $1810 \mathrm{Md}$. Laws ch. 15, $\S 1-2$.

Another section of that statute protected free negroes from sale as a slave. Sale as a slave of a person bound only to serve a period of years was already a crime. Evasion and loss of freedom were further protected by prohibiting the sale of such an individual out of state. The loophole left was that masters could sell their servants within the state to buyers who might then take the servants out of the state and treat them as slaves. The last section prohibited the sale of any servant or slave entitled to freedom after a period of years to any person who was not a bona fide resident of the state and who had not been in the state for at least one year. Id., $\$ 3$.

Another statute of 1810 gave procedural advantages to slaveowners at the expense of negroes claiming freedom. $1810 \mathrm{Md}$. Laws ch. 63 . The first section put the burden on negroes or mulattoes brought before a court as runaways to demonstrate that they were not runaways. Id. $\$ 1$. The second section permitted removal to the county of residence of a female ancestor allegedly held in bondage to facilitate evidence on that issue. The third section allowed owners to remove the suit to the county of their residence when petitioners, residing in another county with their masters' permission, filed suit in that other county.

102. $1717 \mathrm{Md}$. Laws ch. $13, \S 2$. When the evidence law was passed, the white father of a mulatto child was punishable with servitude, $1715 \mathrm{Md}$. Laws ch. 44, \$27, but the negro mother was not subject to punishment until 1728. $1728 \mathrm{Md}$. Laws ch. $4, \S 3$. Whether the mulatto child was subject to servitude in 1717 was unclear.

103. State v. Fisher, 1 H. \& J. 750 (Md. 1805). 
exclude the evidence indicates the deterioration in the position of free blacks. ${ }^{104}$

In 1808 , the grand jury in Queen Anne's County complained to the House of Delegates over a county court decision that the evidence of a free negro was not admissible against another free negro in capital cases. ${ }^{105}$ The grand jury petition led to swift enactment of a law permitting evidence of any person of color, whether slave or free, to be used either for or against any clefendant of color in any criminal prosecution. ${ }^{106}$ The decision of the Queen Anne's county court excluding free negro testimony against free negroes assumed that such testimony was inadmissible against white defendants. ${ }^{107}$ Exclusion of free negro testimony in cases involving whites may have been common since 1717, but the Court of Appeals' decision in Fisher showed that questions remained open about free mulatto testimony in such suits. The statements of counsel concerning Banneker in Rusk $v$. Sowerwine demonstrated that some lower courts had accepted such testimony. ${ }^{108}$

The case that discussed Banneker's rights proved to be a low point for the free black in Maryland. In Rusk, the plaintiff called Banneker's sister, Minta Black, to testify in a suit between whites over ownership of a slave. The defendant objected to Minta Black's testimony, while the plaintiff insisted that it was admissible and offered to show that courts had accepted her brother's testimony in similar suits. The trial court excluded her testi-

104. The exclusion of freed slave testimony after 1783 assumed that mulatto children of slave rnothers could testify if they had been emancipated prior to that date. $1783 \mathrm{Md}$. Laws Apr. Sess. ch. 23. Mulatto children of white women could testify after their period of servitude, $1717 \mathrm{Md}$. Laws ch. 13, §5, and the statute of 1790 eliminated that servitude. 1790 Md. Laws ch. 9. The possible bases for excluding the testimony of the mulatto child of the negro woman were judicial discretion over the admission of evidence or a definition of "free negro" in the statute of 1717 which included mulattoes.

105. VPMHD (1808), supra note 15, at 22.

106. 1808 Md.Laws ch. 81 .

107. No court would find that evidence admissible to convict white defendants was inadmissible against free negroes.

The 1717 statute provided that evidence of slaves, free negroes, or mulattoes born of a white woman, during their time of servitude by law, could be used against "such negro, mulatto slave, \&c" in the discretion of the court "provided such evidence or testimony do not extend to the depriving them . . . of life or member." 1717 Md. Laws ch. 13, §3. An amendment in 1737 permitted the use of corroborated slave testimony to convict a slave of a capital crime, but it failed to consider free negroes. 1737 Md. Laws Apr. Sess. ch. 7. See 1751 Md. Laws ch. 14, $\$ 4$ (further specifying circumstances for permitting slave testimony). The county court judges may have reasoned that the failure to include free negroes in these amendments meant that they could not be convicted of a capital crime on evidence specifically allowed only for noncapital crimes by the earlier statute.

Since the opinion of the Queen Anne's county court is not reported, it is not clear whether the juclges recognized any distinctions between Historically Free Blacks and Newly Free Blacks or between negroes and mulattoes.

108. Rusk v. Sowerwine, 3 H. \& J. 97, 98-99 (Md. 1810). See text accompanying note 13 supra. 
mony, and the Court of Appeals affirmed its opinion. The trial court dismissed plaintiff's offer of proof concerning Banneker by noting that it did not appear that objections had been made when Banneker was so admitted as a witness and therefore there had been no judicial ruling on the issue. ${ }^{109}$ It held that Minta Black was "an incompetent witness, the plaintiff and defendant being free white christian persons." 110

Minta Black was an Historically Free Black, descended from a white woman. No statute or previous appellate decision precluded the use of her testimony in suits between white parties. The status distinctions among blacks, however, had been so eroded since 1783 that the courts felt confident in treating such individuals as worthy of no more weight in suits involving whites than that afforded slaves. ${ }^{111}$

\section{Prejudice, Equality and Original Intent}

By 1810 , the free black class had expanded enormously from less than eight percent to more than twenty-five percent of the total black population. Freedom, however, meant far less than it did three decades earlier. The different classes of free blacks were merged into one, and that one had fewer rights than ever before. The Banneker family vividly illustrates the impact of the evolving law on the legal status of the free black. Benjamin Banneker was afforded virtually all the legal rights of a white man. His nephew, however, was denied the right to vote in $1802 .^{112} \mathrm{By} 1810$, a trial court would not listen to evidence from his sister, although one had accepted Benjamin Banneker as a witness only a decade before.

The destruction of the rights of free blacks in Maryland following the adoption of the federal constitution in 1787 was not the product of a concerted plan. It was a product of a series of quite disparate concerns: the movement for universal suffrage, the losses suffered by slaveholders from escapes and theft, and the Virginia manumission legislation. The use of race in responding to the challenges these events posed to the society undermined earlier ideas of the citizenship of free blacks and the right of all men to equal treatment under the law. Ultimately, the attempt to protect slavery and the existing political system poisoned the entire society with a racism that remains long after slavery and the laws of slavery disappeared.

109. Id.

110. Id.

111. The testamentary barrier did not apply to petitions for freedom. The failure of legislative attempts to exclude testimony of Historically Free Blacks who had been held in bondage was persuasive evidence that such testimony was admissible. Thus in 1814 the Court of Appeals concurred in the opinion of the county court which overruled the objection of a white defendant in a petition-for-freedom action to the admission of testimony of a mulatto man who had won his freedom in such a suit in 1795. Sprigg v. Negro Mary, 3 H. \& J. 491 (Md. 1814).

112. See Bogen, supra note 24. 
Taney wrote Dred Scott with the hindsight of eight decades. He believed citizenship for free blacks was unthinkable to the framers in 1787 because it was unthinkable to him in 1857 . In this he was wrong. Racial prejudice was strong in the early years of the nation, but the framers could have believed it possible for slavery and racial prejudice to coexist with the ideal of equality under the law for all free men. Fifty years later, Taney saw that they could not. His tragedy lay in choosing prejudice over equality as the aspect of the framers' thought that would prevail. It was a choice that reflected the legal developments in his native Maryland after the ratification of the Constitution. 